\title{
T Lymphocyte-mediated Protection against Pseudomonas aeruginosa Infection in Granulocytopenic Mice
}

\author{
William G. Powderly, Gerald B. Pier, and Richard B. Markham \\ Departments of Medicine and of Microbiology and Immunology, Washington University School of Medicine, and The Jewish Hospital at \\ Washington University Medical Center, St. Louis, Missouri 63110; and The Channing Laboratory, Department of Medicine, \\ Brigham and Women's Hospital, Harvard Medical School, Boston, Massachusetts 02115
}

\begin{abstract}
BALB/c mice immunized with Pseudomonas aeruginosa immunotype 1 polysaccharide develop protective $T$ cell immunity to bacterial challenge. In vitro, $T$ cells from immunized mice kill $P$. aeruginosa by production of a bactericidal lymphokine. The present study demonstrates that adoptive transfer of $T$ cells from immunized BALB/c mice to granulocytopenic mice resulted in 97\% survival on challenge with $\boldsymbol{P}$. aeruginosa, compared with $17 \%$ survival with adoptive transfer of $T$ cells from nonimmune BALB/c mice. This protection is specifically elicited by reexposure to the original immunizing antigen; adoptive recipients cannot withstand challenge with immunotype $3 P$. aeruginosa. However, the adoptive recipients do survive simultaneous infection with both $P$. aeruginosa immunotypes 1 and 3 . Adoptive transfer of $T$ cells from the congenic CB.20 mice, which are unable to kill $P$. aeruginosa in vitro, provides only $20 \%$ protection to granulocytopenic mice. These studies indicate that transfer of specific immune $T$ lymphocytes can significantly enhance the resistance to $\boldsymbol{P}$. aeruginosa infection in granulocytopenic mice.
\end{abstract}

\section{Introduction}

Analysis of immune resistance to infection with gram-negative extracellular bacteria has focused on the role of antibody, complement, and phagocytic cells in destroying these organisms (1). The predisposition of granulocytopenic patients to develop infection with gram-negative bacteria has been cited as evidence for the importance of these cells in resistance to such infections (2). Pseudomonas aeruginosa ( $P$. aeruginosa) ${ }^{1}$ is an important bacterial pathogen in granulocytopenic hosts and, despite advances in antimicrobial therapy, this organism remains an important cause of morbidity and mortality in such patients (3). Attempts to modulate the course of $P$. aeruginosa infection in

This work was presented in part at the 25th Interscience Conference on Antimicrobial Agents and Chemotherapy, Minneapolis, MN, 1985.

Address correspondence to Dr. Powderly, Jewish Hospital, Washington University Medical Center, 216 South Kingshighway Boulevard, P.O. Box 14109, St. Louis, MO 63173.

Received for publication 2 January 1986.

1. Abbreviations used in this paper: $\mathrm{CFU}$, colony-forming units; Con $\mathrm{A}$, concanavalin A; IL-1, interleukin 1; IT-1, immunotype 1; IT-3, immunotype 3, LPS, lipopolysaccharide; PS, polysaccharide; $P$. aeruginosa, Pseudomonas aeruginosa.

J. Clin. Invest.

(C) The American Society for Clinical Investigation, Inc.

0021-9738/86/08/0375/06 $\$ 1.00$

Volume 78, August 1986, 375-380 leukopenic patients using granulocyte transfusions and serotherapy have had only limited success $(4,5)$.

The role of $\mathrm{T}$ lymphocytes in resistance to infection with gram-negative bacteria has been thought to be limited to regulation of the antibody response. We have previously demonstrated that $\mathrm{T}$ lymphocytes from BALB/c mice given the cytotoxic agent vinblastine sulfate and a polysaccharide (PS) antigen isolated from $P$. aeruginosa immunotype 1 (IT-1) can adoptively transfer resistance to infection to nonimmune mice (6). We also established that splenic $\mathrm{T}$ cells obtained from immunized mice could kill $P$. aeruginosa in vitro (7). After in vitro reexposure to the immunizing antigen, $T$ cells from immune mice secrete a lymphokine that kills a broad range of gram-negative and grampositive bacteria (7). This killing requires the presence of neither antibody nor complement, and it occurs in the absence of phagocytic cells (7).

The murine $\mathrm{T}$ cell that mediates the bactericidal effect is of the Lyt $1^{-}, 2^{+}$phenotype and reacts with monoclonal antibodies directed at the putative I-Jd antigen (8). Macrophages are required in this system only as a source of interleukin 1 (IL-1) (8), and function neither as antigen-presenting cells nor as phagocytic cells. In addition, we have identified a strain of mouse, CB.20, congenic with BALB/c mice at the Igh-1 locus, that fails to kill $P$. aeruginosa in this in vitro model (9). The nonresponsiveness of this strain is attributable to the activity of suppressor $\mathrm{T}$ cells (9).

The current studies were designed to investigate further the in vivo significance of this $\mathrm{T}$ lymphocyte-mediated immune response. Using a murine model of granulocytopenia, we found that adoptive transfer of immune $T$ cells could protect mice from a lethal challenge with $P$. aeruginosa, even in the absence of granulocytes; but protection could not be achieved with nonimmune $T$ cells, nor with immune B cells. $T$ cells from the CB.20 mice, which did not kill $P$. aeruginosa in our in vitro assay, are also incapable of adoptively transferring protection in vivo, establishing that the ability to confer protection correlates with the in vitro bactericidal activity of immune T cells. $P$. aeruginosa IT-1 immune T cells are unable to protect granulocytopenic mice infected with $P$. aeruginosa immunotype 3 (IT-3). Adoptive transfer of IT-1 immune T cells is, however, protective against simultaneous challenge with both $P$. aeruginosa IT-1 and IT-3, indicating that in vivo reexposure to the homologous immunizing antigen elicits a nonspecific protective response.

\section{Methods}

Bacteria. The Fisher-Devlin IT-1 and IT-3 strains of $P$. aeruginosa (originally provided by Dr. M. Fisher, Parke-Davis Co., Detroit, MI) were grown overnight in $20 \mathrm{ml}$ trypticase-soy broth. Bacteria from this growth were inoculated into $20 \mathrm{ml}$ of fresh broth to obtain a relative optical density of 0.05 OD units (35 Spectrophotometer, Perkin-Elmer Corp., 
Coleman Instruments Div., Oak Park, IL) and allowed to grow to a density of $0.20 \mathrm{OD}$ units. These bacteria were then harvested, washed once in $0.15 \mathrm{M} \mathrm{NaCl}$, and resuspended to a concentration of $1 \mathrm{OD}$ unit, which routinely contained $2-3 \times 10^{9}$ colony-forming units $(\mathrm{CFU}) / \mathrm{ml}$ of $P$. aeruginosa. The bacteria were diluted to the appropriate concentration in RPMI 1640 medium (Center for Basic Cancer Research, Washington University School of Medicine) and administered intraperitoneally to granulocytopenic mice in challenge experiments.

Mice. 6-wk-old BALB/c, C3H/HeSn, and CB.20 female mice were obtained from the Animal Resources Facility of The Jewish Hospital of St. Louis.

Cell separation. $\mathrm{T}$ cells were prepared according to the method of Wysocki and Sato (10). Briefly, $3 \times 10^{7}$ murine spleen cells were placed for $70 \mathrm{~min}$ on petri dishes that had been precoated with $50 \mu \mathrm{l}$ of affinitypurified goat antibody to mouse immunoglobulin (Gateway Immunosera, St. Louis, MO). The nonadherent cells were collected and again placed for $70 \mathrm{~min}$ on a second anti-mouse Ig antiserum-coated petri dish. The nonadherent cells collected from this second cycle of adherence routinely contained $<5 \%$ cells that reacted with fluorescein-conjugated goat antibody to mouse Ig. The response of the nonadherent cells to the $T$ cell mitogen concanavalin A (Con A; Pharmacia Fine Chemicals, Piscataway, $\mathrm{NJ}$ ) was generally equivalent to the response of unseparated cells. On the other hand, their response to the B cell mitogen lipopolysaccharide (LPS) obtained from Salmonella enteriditis (Difco Laboratories, Detroit, MI) was routinely reduced by $75 \%$ compared with the response of unseparated spleen cells.

$\mathrm{T}$ cells were depleted from immune spleen cell populations by in cubation for $1 \mathrm{~h}$ at $4^{\circ} \mathrm{C}$ with a monoclonal anti-Thy-1.2 antibody (diluted $1: 250$ in cytotoxicity medium) followed by a 45 -min incubation at $37^{\circ} \mathrm{C}$ in low tox rabbit complement diluted 1:10. The reagents used in the $T$ cell-depleting steps were obtained from Accurate Scientific and Chemical, Westbury, NY. The efficiency of the depletion is indicated in Table III.

Reagents. The bacterial PS used in these studies was prepared by previously described methods (11). Vinblastine sulfate was from Eli Lilly \& Co., Indianapolis, IN. Cyclophosphamide was obtained from BristolMyers Co., Syracuse, NY.

Serologic assay. Murine sera was obtained via retroorbital bleeding of halothane-anesthetized mice. Concentrations of antibody were determined using a radioimmunoassay as described (12). The antigen used was intrinsically labeled ${ }^{14} \mathrm{C}$-PS prepared as described (12). The lower limit of detection in this assay for mouse antibodies is $2 \mu \mathrm{g} / \mathrm{ml}$.

Immunization protocol. $10 \mu \mathrm{g}$ of PS were administered intraperitoneally and $100 \mu \mathrm{g}$ of vinblastine sulfate intravenously to 6-wk-old female mice. Splenic cells were harvested $6 \mathrm{~d}$ after immunization.

Challenge protocol. Granulocytopenia was induced in 6-wk-old female BALB/c mice using the method described by Cryz et al. (13). This model involves the administration of cyclophosphamide, $150 \mu \mathrm{g} / \mathrm{g}$ body wt, intraperitoneally, at 2-d intervals, for a total of three doses. This produces consistent leukopenia (white cell count $<300 / \mathrm{mm}^{3}$ ) for $\sim 4 \mathrm{~d} .8 \mathrm{~h}$ after the final dose of cyclophosphamide, the indicated cells from immune or control mice were transferred via the tail vein. $18 \mathrm{~h}$ later, the mice were challenged intraperitoneally with the indicated number of live $P$. aeruginosa. Preliminary studies had shown that 25 CFU of $P$. aeruginosa IT -1 and IT-3 administered in this fashion killed $>95 \%$ of granulocytopenic mice. Survival was recorded every $24 \mathrm{~h}$ for a total of $168 \mathrm{~h}$ (7 d). All mice surviving at $168 \mathrm{~h}$ had recovered normal white blood cell counts and appeared well. Preliminary studies indicated that no additional deaths occurred after $7 \mathrm{~d}$ (evaluated up to a total of $14 \mathrm{~d}$ ).

Statistics. A generalized savage (Mantel-Cox) test (14) was used to detect differences in rate of death and in overall survival among the challenge groups. Differences in overall survival were also compared by the one-tailed Fisher's exact test (15). $P$ values $<0.05$ were considered significant. Although all tables and texts show only the $P$ values for the Mantel-Cox test (unless otherwise indicated), all differences found to be significant using this test were also significant $(P<0.05)$ using the Fisher's exact test.

\section{Results}

Protection of granulocytopenic mice by adoptive transfer of immune $T$ cells. $T$ lymphocytes from immunized and unimmunized BALB/c mice were adoptively transferred to granulocytopenic BALB/c mice $18 \mathrm{~h}$ before challenge with $P$. aeruginosa, and mouse survival was determined (Table I). In exp. 1, $5 \times 10^{7}$ immune $T$ cells protected $100 \%$ of granulocytopenic mice from intraperitoneal challenge with $100 \mathrm{CFU}$ of $P$. aeruginosa, whereas only $33 \%$ of mice given nonimmune $\mathrm{T}$ cells survived. In the second experiment, granulocytopenic mice were given a lower number of $\mathrm{T}$ lymphocytes $\left(3 \times 10^{7}\right)$ and a larger challenge inoculum ( $260 \mathrm{CFU}$ ). $67 \%$ of the mice given immune $\mathrm{T}$ cells survived, compared with no survival in mice given nonimmune $T$ cells. Furthermore, the mean survival time between the two groups, $144 \pm 19.5 \mathrm{~h}$ for immune $\mathrm{T}$ cells and $44 \pm 4 \mathrm{~h}$ for nonimmune $\mathrm{T}$ cells, was significantly different $(P=0.001)$. Further experiments have shown that adoptive transfer of only $5 \times 10^{6}$ immune $\mathrm{T}$ cells can protect granulocytopenic mice from challenge with 100-150 CFU of $P$. aeruginosa (not shown).

Previous work has demonstrated that the development of a protective immune response in vivo (6) and the development of a bactericidal $T$ cell response in vitro (7) requires immunization with both PS and vinblastine. Although the mechanism of action of vinblastine in this system is not fully defined, preliminary evidence indicates that vinblastine eliminates a suppressor cell that inhibits the killing capability of the bactericidal $T$ cells (15a). To confirm that the adoptively transferred in vivo protection correlates with our in vitro observations, we compared survival in granulocytopenic mice given $T$ cells from mice immunized with both PS and vinblastine to survival in granulocytopenic mice given $\mathrm{T}$ cells from donor mice immunized with either PS. or vinblastine alone. T lymphocytes from mice immunized with both PS and vinblastine protected $100 \%$ of mice challenged with $P$. aeruginosa, whereas there was no survival in mice given cells from either mice immunized with vinblastine (Table II, exp. 1) or with PS (Table II, exp. 2).

Table I. Protection of Granulocytopenic Mice against Challenge with P. aeruginosa by Adoptive Transfer of Immune T Cells

\begin{tabular}{|c|c|c|c|c|}
\hline $\begin{array}{c}\text { Group Cells given } \\
\text { (source) }\end{array}$ & $\begin{array}{l}\text { No. of cells } \\
\left(\times 10^{7}\right)\end{array}$ & $\begin{array}{l}\text { No. of survivors/ } \\
\text { total recipients }\end{array}$ & $\begin{array}{l}\text { Mean } \pm \text { SEM } \\
\text { survival* }\end{array}$ & $\begin{array}{l}P \\
\text { valuef }\end{array}$ \\
\hline & & \% survival & $h$ & \\
\hline \multicolumn{5}{|l|}{ Exp. $1 \S$} \\
\hline \multicolumn{5}{|l|}{$1 \mathrm{~T}$ cells (immune } \\
\hline $\mathrm{BALB} / \mathrm{c})$ & 5 & $6 / 6(100)$ & 168 & \\
\hline \multicolumn{5}{|l|}{$2 \mathrm{~T}$ cells (nonimmune } \\
\hline BALB/c) & 5 & $2 / 6(33)$ & $112 \pm 19$ & 0.02 \\
\hline \multicolumn{5}{|l|}{ Exp. $2 \S$} \\
\hline \multicolumn{5}{|l|}{$1 \mathrm{~T}$ cells (immune } \\
\hline $\mathrm{BALB} / \mathrm{c})$ & 3 & $4 / 6(66)$ & $144 \pm 19$ & \\
\hline \multicolumn{5}{|l|}{$2 \mathrm{~T}$ cells (nonimmune } \\
\hline BALB/c) & 3 & $0 / 6(0)$ & $44 \pm 4$ & 0.001 \\
\hline
\end{tabular}

* Experiments were terminated at $7 \mathrm{~d}$. Maximum survival achievable was $168 \mathrm{~h}$. $¥$ The $P$ value expresses significance of difference between groups 1 and 2 in each experiment (Mantel-Cox test).

$\S$ The number of bacteria given was 100 per mouse in exp. 1 and 260 in exp. 2 . 
Table II. Inability of PS or Vinblastine (Vin) Alone to Induce Protective T Cell Immunity

\begin{tabular}{|c|c|c|c|c|}
\hline $\begin{array}{l}\text { Immunization } \\
\text { protocol }\end{array}$ & $\begin{array}{l}\text { No. of cells } \\
\left(\times 10^{7}\right)\end{array}$ & $\begin{array}{l}\text { No. of survivors/ } \\
\text { total recipients }\end{array}$ & $\begin{array}{l}\text { Mean } \pm \text { SEM } \\
\text { survival* }\end{array}$ & $\begin{array}{l}P \\
\text { valueł }\end{array}$ \\
\hline & & \% survival & $h$ & \\
\hline \multicolumn{5}{|l|}{ Exp. $1 \S$} \\
\hline $1 \mathrm{Vin}+\mathrm{PS}$ & 3 & $5 / 5(100)$ & 168 & \\
\hline 2 Vin & 3 & $0 / 5(0)$ & $62 \pm 6$ & 0.003 \\
\hline \multicolumn{5}{|l|}{ Exp. $2 \S$} \\
\hline $1 \mathrm{Vin}+\mathrm{PS}$ & 5.4 & $5 / 5(100)$ & 168 & \\
\hline 2 PS & 5.4 & $0 / 5(0)$ & $77 \pm 19$ & 0.006 \\
\hline
\end{tabular}

* Experiments were terminated at $7 \mathrm{~d}$. Maximum survival achievable is $168 \mathrm{~h}$.

$¥$ The $P$ value expresses significance of difference between groups 1 and 2 in each experiment (Mantel-Cox test).

$\S$ The number of bacteria given was 130 per mouse in exp. 1 and 150 in $\exp 2$.

Inability of $B$ lymphocytes to transfer protection. Immune spleen cell populations were selectively depleted of lymphocytes bearing either the Thy-1.2 determinant (found on $\mathrm{T}$ cells) or surface Ig (found on B cells). The selected populations were transferred to nonimmune granulocytopenic recipient mice that were challenged $18 \mathrm{~h}$ later with $P$. aeruginosa. The results (Table III) indicated that the effector cell transferring protection was removed by antisera directed at the Thy- 1.2 determinant $(0 \%$ survival) and not by antisera directed at the Ig determinants (100\% survival).

Although the dosage of PS used in the immunization protocol in these experiments is not associated with the development of an antibody response in BALB/c mice, we still measured antibody levels in recipient granulocytopenic mice before and after adoptive transfer of immune $T$ cells. No detectable antibody was found after adoptive transfer, confirming that protection is not mediated by passive transfer of antibody. Control mice of

Table III. Comparison of Ability of T Cells and $B$ Cells from Immunized BALB/c Mice to Protect Granulocytopenic Mice from Challenge with P. aeruginosa

\begin{tabular}{|c|c|c|c|c|c|}
\hline \multirow{2}{*}{$\begin{array}{l}\text { Cells given } \\
\text { (source) }\end{array}$} & \multirow{2}{*}{$\begin{array}{l}\text { No. of cells } \\
\left(\times 10^{7}\right)\end{array}$} & \multicolumn{2}{|c|}{$\begin{array}{l}\mathrm{SI}^{*} \text { of } \\
\text { mitogens }\end{array}$} & \multirow{2}{*}{$\begin{array}{l}\text { No. of survivors/ } \\
\text { total recipients }\end{array}$} & \multirow{2}{*}{$\begin{array}{l}\text { Mean } \pm \text { SEM } \\
\text { survival§ }\end{array}$} \\
\hline & & Con A & LPS & & \\
\hline & & & & \% survival & $h$ \\
\hline $\begin{array}{l}\text { Anti-lg-treated } \\
\text { spleen cells } \\
\text { Anti-Thy- }\end{array}$ & 2.5 & 8.9 & 0.8 & $5 / 5(100)$ & 168 \\
\hline spleen cells & 2.5 & 2.9 & 2.8 & $0 / 5(0)$ & $34 \pm 10^{\prime \prime}$ \\
\hline
\end{tabular}

* SI, stimulation index; cpm, mitogen-stimulated cultures per cpm, unstimulated cultures. SI for unseparated spleen cells were: Con A, 17.8; LPS, 4.2. $\ddagger 150$ bacteria were administered to each mouse.

§ Experiments were terminated at $7 \mathrm{~d}$. Maximum survival achievable is $168 \mathrm{~h}$.

"Significance of difference between two groups, $P=0.002$ (Mantel-Cox test). the $\mathrm{C} 3 \mathrm{H} / \mathrm{HeSn}$ strain, which do develop an antibody response after low dose immunization, had concentrations of $13.5 \mu \mathrm{g} / \mathrm{ml}$ specific antibody in their serum after immunization compared with no detectable antibody before immunization.

Failure of $T$ cells from $C B .20$ mice to transfer protection. CB.20 mice, which are congenic with BALB/c and known to differ only at the Igh-1 allotype locus (16), fail to generate a bactericidal $\mathrm{T}$ cell response after immunization with PS and vinblastine (9). We therefore compared the ability of immune $T$ cells from CB.20 mice to protect granulocytopenic BALB/c mice with the protective ability of immune $T$ cells transferred from BALB/c mice. The results of two such experiments are shown in Table IV. Both experiments show that immune cells from BALB/c mice protected $100 \%$ of challenged granulocytopenic mice compared with $20 \%$ protection with cells from immunized CB.20 mice. CB.20 and BALB/c mice are identical at the major histocompatibility ( $\mathrm{H}-2)$ locus, but it is uncertain whether these two strains are identical at other minor histocompatibility sites. That the inability of CB.20 T cells to protect granulocytopenic BALB/c mice is not due to minor histoincompatibilities is shown by the ability of $T$ cells from immunized BALB/c mice to protect $100 \%$ of infected granulocytopenic CB.20 mice (Table V).

Specificity of $T$ cell-mediated protection. Previous studies have shown that the in vitro bactericidal activity of $\mathrm{T}$ lymphocytes obtained from mice immunized with IT-1 PS is specific for the immunizing immunotype (7). We examined the effectiveness of adoptively transferred $T$ cells obtained from mice immunized with IT-1 PS in infection with $P$. aeruginosa IT-3 to determine the in vivo specificity of the protection. IT-1 immune $\mathrm{T}$ cells, which protect $100 \%$ of granulocytopenic mice infected with $P$. aeruginosa IT-1 (Table VI, group 1), are unable to protect granulocytopenic mice infected with $P$. aeruginosa IT-3 (group 2, 20\% survival) and are equivalent to nonimmune $\mathrm{T}$ cells in these mice.

Effectiveness of $P$. aeruginosa IT-1 immune T cells in transferring protection to granulocytopenic mice simultaneously in-

Table IV. Inability of T Cells from Immunized CB.20 Mice to Protect Granulocytopenic Mice from Live Bacterial Challenge

\begin{tabular}{|c|c|c|c|c|}
\hline $\begin{array}{c}\text { Group Cells given } \\
\text { (source) }\end{array}$ & $\begin{array}{l}\text { No. of cells } \\
\left(\times 10^{7}\right)\end{array}$ & $\begin{array}{l}\text { No. of survivors/ } \\
\text { total recipients }\end{array}$ & $\begin{array}{l}\text { Mean } \pm \text { SEM } \\
\text { survival }^{*}\end{array}$ & $\begin{array}{l}P \\
\text { valueł }\end{array}$ \\
\hline & & \% survival & $h$ & \\
\hline \multicolumn{5}{|c|}{ Exp. $1 \S$} \\
\hline \multicolumn{5}{|c|}{$1 \mathrm{~T}$ cells (immune } \\
\hline BALB/c) & 5.7 & $5 / 5(100)$ & 168 & \\
\hline \multicolumn{5}{|c|}{$2 \mathrm{~T}$ cells (immune } \\
\hline CB.20) & 5.7 & $1 / 5(20)$ & $77 \pm 19$ & 0.006 \\
\hline \multicolumn{5}{|c|}{ Exp. $2 \S$} \\
\hline \multicolumn{5}{|c|}{1 T cells (immune } \\
\hline BALB/c) & 4.5 & $5 / 5(100)$ & 168 & \\
\hline \multicolumn{5}{|c|}{$2 \mathrm{~T}$ cells (immune } \\
\hline CB.20) & 4.5 & $1 / 5(20)$ & $110 \pm 17$ & 0.01 \\
\hline
\end{tabular}

* Experiments were terminated at $7 \mathrm{~d}$. Maximum survival was $168 \mathrm{~h}$. $¥$ The $P$ value expresses significance of difference between groups 1 and 2 in each experiment (Mantel-Cox test).

$\S$ The number of bacteria given was 230 per mouse in exp. 1 and 150 in exp. 2. 
Table $V$. Ability of $T$ Cells from Immunized

$B A L B / c$ Mice to Protect Granulocytopenic

CB.20 Mice from Live Bacterial Challenge

\begin{tabular}{llll}
\hline Cells given (source) & $\begin{array}{l}\text { No. of cells } \\
\left(\times 10^{7}\right)\end{array}$ & $\begin{array}{l}\text { No. of survivors/ } \\
\text { total recipients* }\end{array}$ & $\begin{array}{l}\text { Mean } \pm \text { SEM } \\
\text { survival } \ddagger\end{array}$ \\
\hline $\begin{array}{l}\text { T cells (immune } \\
\text { BALB/c) }\end{array}$ & 3.9 & $5 / 5(100)$ & $h$ \\
$\begin{array}{l}\text { T cells (nonimmune } \\
\text { BALB/c) }\end{array}$ & 3.9 & $0 / 5(0)$ & $62 \pm 6 \S$ \\
\hline
\end{tabular}

* The number of bacteria given was 170 per mouse.

‡ Experiments were terminated at $7 \mathrm{~d}$. Maximum survival was $168 \mathrm{~h}$. $\S$ Significance of difference between the two groups, $P=0.003$.

fected with $P$. aeruginosa IT-1 and IT-3. In vitro studies have demonstrated that the $\mathrm{T}$ cell-mediated bactericidal effect can be attributed to the activity of a bactericidal lymphokine, which, once elicited by specific antigenic challenge of immune $T$ cells, is nonspecifically effective against a broad range of both gramnegative and gram-positive bacteria (7). The previous experiment confirmed in vivo that challenge with an unrelated antigen does not activate protective $T$ cell immunity. In this experiment we evaluated whether activating protective $T$ cell immunity by challenge with the homologous antigen ( $P$. aeruginosa IT-1) could protect against simultaneous infection with an unrelated antigen ( $P$. aeruginosa IT-3). The results of a representative experiment (Table VII) indicate that such cross-protection can, in fact, be elicited. $86 \%$ of granulocytopenic mice that received IT- 1 immune $\mathrm{T}$ cells survived simultaneous challenge with IT1 and IT-3 $P$. aeruginosa. Granulocytopenic mice receiving nonimmune $T$ cells did not survive challenge with the two immunotypes, and no survival was seen in granulocytopenic mice that received IT-1 immune T cells and were challenged with IT$3 P$. aeruginosa. These observations suggest that in vivo the final mediator of protection is nonspecific in its effect, but this nonspecific protection can only be elicited by exposure to the original immunizing antigen, the PS from IT-1 P. aeruginosa.

Table VI. Specificity of Protection Transferred by IT-1-Immune T Cells

\begin{tabular}{lllll}
\hline Group & $\begin{array}{l}\text { Immune status } \\
\text { of donor mice* }\end{array}$ & $\begin{array}{l}\text { Bacterial } \\
\text { challenge } \\
\text { immunotypeł }\end{array}$ & $\begin{array}{l}\text { No. of survivors/ } \\
\text { total recipients }\end{array}$ & $\begin{array}{l}\text { Mean } \pm \text { SEM } \\
\text { survival§ }\end{array}$ \\
\hline & & & \% survival & $h$ \\
1 & Immune & IT-1 & $5 / 5(100)$ & 168 \\
2 & Immune & IT-3 & $1 / 5(20)$ & $67 \pm 26^{\| \prime}$ \\
3 & Nonimmune & IT-3 & $1 / 5(20)$ & $62 \pm 27^{\prime \prime}$ \\
\hline
\end{tabular}

* $4.9 \times 10^{7}$ cells transferred per mouse.

$¥$ The number of bacteria given was 180 IT-1 and 210 IT -3 per mouse.

$\S$ Experiments were terminated at $7 \mathrm{~d}$. Maximum survival was $168 \mathrm{~h}$.

" $P$ value of difference between groups 1 and 2 (Mantel-Cox test), 0.02 .

$P$ value of difference between groups 2 and 3 (Mantel-Cox test), 0.7.
Table VII. Cross-protection against Simultaneous

Challenge with Two Immunotypes of $P$. aeruginosa

\begin{tabular}{lllll}
\hline Group & $\begin{array}{l}\text { Immune status } \\
\text { of donor mice* }\end{array}$ & $\begin{array}{l}\text { Bacterial } \\
\text { challenge } \\
\text { immunotype }\end{array}$ & $\begin{array}{l}\text { No. of survivors/ } \\
\text { total recipients }\end{array}$ & $\begin{array}{l}\text { Mean } \pm \text { SEM } \\
\text { survival§ }\end{array}$ \\
\hline & & & $\%$ survival & $h$ \\
1 & IT-1 immune & IT-1, IT-3 & $5 / 6(86)$ & $152 \pm 14$ \\
2 & Nonimmune & IT-1, IT-3 & $0 / 6(0)$ & $48 \pm 6^{\text {II }}$ \\
3 & IT-1 immune & IT-3 & $0 / 6(0)$ & $53 \pm 5$ \\
4 & IT-1 immune & IT-1 & $4 / 4(100)$ & $168 \pm 0$ \\
\hline
\end{tabular}

* $3.2 \times 10^{7} \mathrm{~T}$ cells transferred per mouse.

¥ The number of bacteria given was 110 IT-1 and 115 IT-3 per mouse.

$\S$ Experiments were terminated at $7 \mathrm{~d}$. Maximum survival was $168 \mathrm{~h}$.

" $P$ value of difference between groups 1 and 2 (Mantel-Cox test), 0.002 .

\section{Discussion}

We have previously observed that BALB/c mice fail to produce specific antibody when immunized with low doses of a purified PS obtained from $P$. aeruginosa. Nevertheless, these mice are capable of generating protective immunity that is mediated by $T$ lymphocytes (6). T lymphocytes from immune mice can transfer protection to nonimmune, immunologically intact mice that are given an otherwise lethal challenge of $10^{8} P$. aeruginosa (6). In vitro Lyt $1^{-}, 2^{+}, I_{-} \mathrm{J}^{+} \mathrm{T}$ cells from BALB/c mice immunized with PS and vinblastine kill $P$. aeruginosa by secretion of a bactericidal lymphokine $(7,8)$. This killing mechanism is remarkably independent of the function of other cells, including macrophages, except that the presence of IL-1, provided by macrophages, results in significant enhancement of the observed $T$ cell-mediated killing (8). T cells from immunized CB.20 mice, which are congenic with BALB/c mice at the Igh-1 locus, fail to kill $P$. aeruginosa in vitro (9). This failure is attributable to the activity of a population of suppressor $\mathrm{T}$ cells generated in CB.20 mice by PS immunization (9).

The studies reported here extend these observations in several important ways and suggest that this novel method of bactericidal activity may have in vivo significance. First, we have shown that immune $\mathrm{T}$ lymphocytes can protect immunosuppressed mice from lethal challenge with $P$. aeruginos $a$ even in the absence of an adequate number of circulating granulocytes, of specific antibody, or of autologous lymphocyte subpopulations. This indicates that, as occurs in vitro (7), T lymphocytes act in vivo as the final effector cell. Secondly, by demonstrating that $\mathrm{T}$ cells from the congenic CB.20 mice fail to protect granulocytopenic mice, we have shown that the ability of immune $T$ cells to transfer protection is correlated with the ability of those cells to kill $P$. aeruginosa in vitro. The in vivo differences in the protective capability of T cells from BALB/c and CB. 20 mice suggest that the Igh-1 locus might be important in determining resistance to infection. This possibility is currently under investigation in our laboratory.

Polysaccharides have traditionally been viewed as thymus independent antigens because helper $\mathrm{T}$ cells are not required to elicit an antibody response. However, studies in the early 1970s 
have shown that PS-activated regulatory $\mathrm{T}$ cells can have a profound effect on the magnitude of the antibody response $(17,18)$. Our studies and those of others $(19,20)$ clearly indicate that PSactivated $\mathrm{T}$ cells may function not merely as regulatory cells but also as effector cells in resistance to bacterial infection.

Control of viral infection by immune $T$ cells has been shown to be directed only at the eliciting antigen and to require direct cell-to-cell contact. Clones of cytolytic $\mathrm{T}$ cells directed against specific influenza virus strains are unable to protect mice simultaneously infected with two strains of influenza virus (21). However, our studies indicate that such specificity is not required in vivo with the $\mathrm{T}$ cell response elicited by $P$. aeruginosa $\mathrm{PS}$, provided there is reexposure to the immunizing antigen. This observation correlates with the in vitro finding that secretion of a bactericidal lymphokine with broad antibacterial activity occurs when immune $T$ lymphocytes are reexposed to the immunizing antigen (7). These studies therefore support the hypothesis that in vivo protection is mediated by secretion of a nonspecifically effective bactericidal lymphokine.

In addition to demonstrating the protective efficacy of immune $\mathrm{T}$ cells in the granulocytopenic mouse, these investigations also provide some preliminary indication of how immune $\mathrm{T}$ cells might function in the intact host to prevent infection. It is clear that circulating immune $T$ cells are capable of controlling localized infections (intraperitoneal in the current studies) with extracellular bacteria in the absence of circulating granulocytes or antibody. While circulating antibody is undoubtedly more efficient at promoting opsonization of overwhelming numbers of bacteria, most infections, including those in leukopenic hosts, begin with the appearance of small numbers of bacteria at an otherwise sterile site within the host (22).

Using our PS immunization protocol, T cell immunity to $P$. aeruginosa is generated more readily than antibody-mediated immunity (23), and this finding is consistent with other studies showing that $\mathrm{T}$ cells are activated by smaller amounts of antigen than are $B$ cells $(24,25)$. It is, therefore, likely that many individuals exposed to Pseudomonas antigens may develop $\mathrm{T}$ cell immunity without possessing protective levels of antibody. In vitro studies in our laboratory indicate that anti-Pseudomonas bactericidal capability of human $\mathrm{T}$ cells is, in fact, more prevalent than protective levels of antibody (11) (Markham, R. B., unpublished observations).

Immunization of mice with PS alone does not elicit a bactericidal response in vitro (7) or a protective response in vivo (6). Vinblastine is required for an optimal response and functions by the inhibition of a population of suppressor cells generated in response to PS immunization (15a). However, ongoing work in our laboratory has demonstrated that exposure to as few as $10^{2}$ live $P$. aeruginosa can generate splenic T lymphocytes that are bactericidal in vitro and capable of adoptively transferring resistance to lethal infection in vivo (Markham R. B., J. J. Goellner, G. B. Pier and W. G. Powderly, manuscript submitted for publication). It therefore becomes reasonable to hypothesize that T cell immunity to extracellular bacteria may, with these bacteria, be a more primitive first line of defense against infection and may play a critical role in the prevention of established infections that could result from the frequent low level of bacterial invasion encountered by the normal host.

Attemps to reconstitute resistance to infection in leukopenic hosts with transfusion of granulocytes has had only limited suc- cess (26), perhaps due in part to the requirement for more complex immune responses, such as antibody production, for optimal neutrophil function (27). Our studies demonstrate that immune T cells can protect granulocytopenic mice from lethal $P$. aeruginosa infection without the additional requirement of antibody or phagocytic cells. Since, as in our model, infection in the immunosuppressed human host begins with localized infections (22), it would now seem appropriate to study the ability of enhancing $\mathrm{T}$ cell immunity to reduce the incidence of infectious complications in the immunosuppressed patient.

\section{Acknowledgments}

We thank Dr. J. R. Little for his critical review of the manuscript.

This work was supported by a grant from the Council for Tobacco Research, USA, Inc., and by U.S. Public Health Service grants AI-15353, AI-22456, and AI-22535 from National Institutes of Health.

\section{References}

1. Young, L. S., W. J. Martin, R. D. Meyer, R. J. Weinstein, and E. T. Anderson. 1977. Gram-negative rod bacteremia: microbiologic, immunologic and therapeutic considerations. Ann. Intern. Med. 86:456471.

2. Bodey, G. P., M. Buckley, Y. S. Sathe, and E. J. Freireich. 1966. Quantitative relationships between circulating leukocytes and infection in patients with acute leukemia. Ann. Intern. Med. 64:328-336.

3. Schimpff, S. C., W. H. Greene, V. M. Young, and P. H. Wiernik. 1974. Significance of Pseudomonas aeruginosa in the patient with leukemia or lymphoma. J. Infect. Dis. 130:\$24-S31.

4. Schiffer, C. A. 1984. Current status of granulocyte transfusion therapy. In Current Clinical Topics in Infectious Diseases, Vol. 5. J. S. Remington, M. N. Swartz, editors. McGraw-Hill, Inc., New York. 189209.

5. Young L. S. 1984. Immunoprophylaxis and serotherapy of bacterial infections. Am. J. Med. 76:664-671.

6. Pier, G. B., and R. B. Markham. 1982. Induction in mice of cellmediated immunity to Pseudomonas aeruginosa by high molecular weight polysaccharide and vinblastine. J. Immunol. 128:2121-2125.

7. Markham, R. B., J. Goellner, and G. B. Pier. 1984. In vitro T cellmediated killing of Pseudomonas aeruginosa. I. Evidence that a lymphokine mediates killing. J. Immunol. 133:962-968.

8. Markham, R. B., G. B. Pier, J. Goellner, and S. B. Mizel. 1985. In vitro $\mathrm{T}$ cell-mediated killing of Pseudomonas aeruginosa. II. The role of macrophages and T cell subsets in T cell killing. J. Immunol. 134: 4112-4117.

9. Powderly, W. G., G. B. Pier, and Markham, R. B. 1986. In vitro T cell-mediated killing of Pseudomonas aeruginosa. III. The role of suppressor T cells in nonresponder mice. J. Immunol. 136:299-303.

10. Wysocki, L. J., and V. L. Sato. 1978. "Panning" for lymphocytes: a method for cell selection. Proc. Natl. Acad. Sci. USA. 75:2844-2848.

11. Pier, G. B. 1982. Safety and immunogenicity of high molecular weight polysăccharide vaccine from immunotype 1 Pseudomonas aeruginosa. J. Clin. Invest. 69:303-308.

12. Pier, G. B., R. B. Markham, and D. D. Eardley. 1981. Correlation of the biological responses of $\mathrm{C} 3 \mathrm{H} / \mathrm{HeJ}$ mice to endotoxin with the chemical and structural properties of the lipopolysaccharides from Pseudomonas aeruginosa and Escherichia coli. J. Immunol. 127:184-187.

13. Cryz, S. J., Jr., E. Furer, and R. Germanier. 1983. Simple model for the study of Pseudomonas aeruginosa infections in leukopenic mice. Infect. Immun. 39:1067-1071.

14. Mantel, N., and W. Haenzel. 1959. Statistical aspects of the anal- 
ysis of data from the retrospective studies of disease. J. Nat. Cancer Inst. 22:719-748.

15. Armitage, P. 1971. Statistical analysis in medical research. Blackwell Scientific Publications, Oxford. 135-138.

15a. Powderly, W. G., G. B. Pier, and R. B. Markham. 1986. In vitro T cell-mediated killing of Pseudomonas aeruginosa. IV. Nonresponsiveness in polysaccharide-immunized BALB/c mice is attributable to vinblastine-sensitive suppressor cells. In press.

16. Lieberman; R. 1978. Genetics of the $\mathrm{IgCH}$ (allotype) locus in the mouse. Springer Semin. Immunopathol. 1:7-30.

17. Baker, P. J., P. W. Stashak, D. F. Amsbaugh, B. Prescott, and R. F. Barth. 1970. Evidence for the existence of two functionally distinct types of cells which regulate the antibody response to type III pneumococcal polysaccharide. J. Immunol. 105:1581-1583.

18. Baker, P. J., N. D. Reed; P. W. Stashak, D. F. Amsbaugh, and B. Prescott. 1973. Regulation of the antibody response to type III pneumococcal polysaccharide. I. Nature of regulatory cells. J. Exp. Med. 137: 1431-1441.

19. Onderdonk, A. B., R. B. Markham, D. F. Zaleznik, R. L. Cisneros, and D. L. Kasper. 1982. Evidence for $T$ cell dependent immunity to Bacteroides fragilis in an intraabdominal abscess model. J. Clin. Invest. 69:9-16.

20. Shapiro, M. E., A. B. Onderdonk, D. L. Kasper, and R. W. Finberg. 1982. Cellular immunity to Bacteroides fragilis capsular polysaccharide. J. Exp. Med. 155:1188-1197.
21. Lukacher, A. E., V. L. Braciale, and T. J. Braciale. 1984. In vivo effector function of Influenza virus-specific cytotoxic $\mathrm{T}$ lymphocyte clones is highly specific. J. Exp. Med. 160:814-826.

22. Schimpff, S. C., V. M. Young, W. H. Greene, G. D. Vermeulen, M. K. Moody, and P. H. Wiernik. 1972. Origin of infection in acute nonlymphocytic leukemia: significance of hospital acquisition of potential pathogens. Ann. Intern. Med. 77:707-714.

23. Markham, R. B., and G. B. Pier. 1983. Characterization of the antibody response in inbred mice and in humans to a high molecular weight polysaccharide antigen from immunotype I Pseudomonas aeruginosa. Infect. Immun. 41:232-236.

24. Baker, P. J., P. W. Stashak, D. F. Amsbaugh, and B. Prescott. 1974. Regulation of the antibody response to Type III pneumococcal polysaccharide. IV. Role of suppressor T cells in the development of low-dose paralysis. J. Immunol. 112:2020-2026.

25. Mitchison, N. A. 1971. The relative ability of $T$ and $B$ lymphocytes to see protein antigens. In Cell Interactions and Receptor Antibodies in Immune Responses. O. Makela, A. Cross, and T. U. Kosunen, editors. Academic Press, Inc., New York. 249-260.

26. Winston, D. F., W. G. Ho, and R. P. Gale. 1982. Therapeutic granulocyte transfusions for documented infection. A controlled trial in ninety-five infectious granulocytopenic episodes. Ann. Intern. Med. 97: 509-515.

27. Stossel, T. P. 1975. Phagocytosis. Recognition and ingestion. Semin. Hematol. 12:83-116. 